УДК 793.3+7.072.3(477)

Підлипська Аліна Миколаӥвна кандидат мистецтвознавства, Київський національний університет культури і мистецть, Київ, Украӥна, alinaknukim@rambler.ru

\title{
КРИТИКА ХОРЕОГРАФІЧНОГО МИСТЕЦТВА В СУЧАСНІЙ УКРАЇНІ
}

Мета дослідження - проаналізувати сучасну ситуацію у царині критичного осмислення явищ хореографічного мистецтва в Україні. Методи дослідження посднують систематизацію інформації щодо становлення та розвитку критичної думки у сфері хореографіі, порівняння наявних часописів танцювальної тематики України та світу, аналіз критично-оцінного дискурсу хореографічної культури в Україні. Наукова новизна статті полягає у виявленні проблем сучасної критики хореографічного мистецтва в Україні. Висновки. У статті наголоштено, що нині в Україні відчутний брак професійних критиків хореографічного мистецгва, що знають історію вітчизняного та світового балету, розуміють його поступ. Зазначено, що відсутність офіційного періодичного видання хореографічної тематики за підтримки державних структур, ситуація низької вербальної активності професійної спільноти, відсутність у більшості фахівців хореографічного мистецтва сформованого ставлення до критики як необхідної умови розвитку танцювальної культури несприятливо позначаються на професійній хореографічній критиці. Вважаємо, що пожвавлення практичної хореографічної сфери (збільшення кількості оригінальних балетмейстерських творів, розпиирення фестивально-конкурсного руху, прихід нової генерації обдарованих виконавців тощо) сприятиме відродженню традицій професійної хореографічної критики.

Ключові слова: критика хореографії, танцювальний журнал, танець хореографія, балет, хореологія.

Пидльпская Алина Николаевна, кандидат искусствоведения, Киевский национальный университет культуры и искуссть, Киев, Ужраина

Критика хореографического искусства в современной Украине

Цель исследования - проанализировать современную ситуацию в области критического осмысления явлений хореографическо гоискусства в Украине. Методы исследования сочетают систематизацію информации по становлению и развитию критической мысли сферы хореографии, сравнение имеющихся 
журналов тащщевальной тематики Украины и мира, аналіз критически-оценочного дискурса сферы хореографической культуры в Украине. Научная новизна статьи заключается в выявлении проблем сферы современной критики хореографического искусства в Украине. Выводы. В статье отмечается, что сегодня в Украине ощутимый недостаток профессиональных критиков хореографического искусства, которые знают историю отечественного и мирового балета, понимают тенденции его развития. Указано, что отсутствие официального периодического издания хореографической тематики, поддерживаемого государственными структурами, ситуація низкой вербальной активности профессионального сообщества, отсутствие у большинства специалистов сферы хореографического искусства сформированного отношения к критике как необходимому условию развития танцевальной культуры не благоприятно сказываются на профессиональной хореографической критике. Считаем, что оживление практической хореографической сферы (увеличение количества оригинальных балетмейстерських произведений, расширение фестивально-конкурсного движения, приход нового поколения одаренных исполнителей и т. д.) будет способствовать возрождению традиций профессиональной хореографической критики.

Ключевые слова: критика хореографи, танцевальный журнал, танец, хореография, балет, хореология.

Alina Pidlypska, PhD in Art History, Kyiv National University of Culture and Arts, Kyiv, Ukraine

\section{Criticism of choreographic art in contemporary Ukraine}

The purpose of the research is to analyze the current situation in the field of eritical interpretation of the phenomena of choreographic art in Ukraine. The research methodology consisted in a combination of systematization of the information on the formation and development of critical thinking in the field of choreography, the comparison of current publications on the subject in Ukraine and the world, and the analysis of the critical-evaluative discourse of choreographic culture in Ukraine. The scientific novelty of the article lies in the identification of the problems of contemporary criticism of choreographic art in Ukraine. Conclusions. The article stresses that contemporary Ukraine is experiencing a tangible shortage of professional critics of choreographic art who know the history of national and world ballet and understand the trends of its development. It was pointed out that the absence of a regular periodical publication on the subject supported by government institutions, the situation of low verbal activity of the professional community, and the lack of a formed attitude to criticism as a necessary prerequisite for the development of dance culture among the specialists in the field of choreographic art adversely affect professional choreographic criticism. We believe that revitalization 
of the practical choreographic sphere (increasing the number of original choreographic productions, expanding the festival and competition movement, the advent of a new generation of gifted performers, etc.) will facilitate the revival of the traditions of professional choreographic criticism.

Key words: criticism of choreography, dance magazine, dance, choreography, ballet, choreology.

Вступ. Важливою складовою будь-якої мистецтвознавчої дисципліни (літературознавство, театрознавство, музикознавство, хореологія тощо) є критика поряд з історією та теорією, оскільки саме критика аналізує та оцінюе повсякденні явища мистецтва, намагаючись виявити їхне значення у сучасності. Проблема вербалізації фахового аналізу явищ танцювальної сфери України $\epsilon$ актуальною у річищі критичного осмислення мистецтв.

Останнім часом активізувалися дослідження у царині аналізу критики різних видів мистецтва: образотворчого (М. Криволапов, Р. Шмагало та ін.), театрального (А. Білик, В. Собіянський та ін.), музичного (Л. Мельник, Ю. Чекан та ін.). На жаль, не виявлено жодного наукового дослідження історичних тенденцій української художньої критики в галузі хореографії. Хоча накопичено великий масив критичних статей, присвячених вітчизняному хореографічному мистецтву, що повинні бути проаналізовані. Зауважимо, що науковий аналіз критично-оцінного дискурсу сфери хореографічного мистецтва важливий для розвитку хореології як науки. Важливим кроком на шляху комплекеного вирішення проблеми с з'ясування сучасного стану критичного осмислення явищ хореографічного мистецтва в Україні.

Мета дослідження - проаналізувати сучасну ситуацію у царині критичного осмислення явищ хореографічного мистецтва в Україні.

Виклад основного матеріалу. У професійному середовищі теоретиків та практиків хореографії поняття «критики» досить часто сприймаєтьея лише

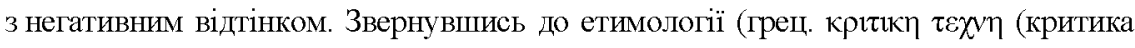
техна) - мистецтво суддівства, розбирання, критики, від крєтๆ - суддя, крıтєко здатний розбирати, судити [2, с. 196]), можна стверджувати, що під критикою слід розуміти «уміння обгрунтовано судити, оціновати, оскаржувати, давати відгук, перевіряти, екзаменувати, виявляти достоїнства й недоліки» [1]. Отже обгрунтований аналіз є провідною рисою професійної критичної оцінки, якої нині бракуе хореографії в Україні.

Зародження критики як оцінного ставлення до твору мистецтва дехто вбачає у висловлюваннях античних філософів, але більш грунтовною видається позиція щодо витоків писемної мистецької критики у добу Просвітництва. 
Естетична спрямованість англійського просвітництва викликала до життя часопис «Спектейтор» («Глядач»), що виходив на початку другого десятиліття XVIII ст. [5] та стимулював формування поняття професійної мистецької критики. «Спектейтор» зумів наблизити публіку до розуміння складних естетичних проблем. Не вдаючись на початку до композиційно-образного аналізу літературних творів (адже зародження критично-оцінного ставлення до мистецтва відбулося саме у літературній сфері), головні проблеми естетичних суперечок значною мірою визначалися моральною цінністю твору. Спектр проблем поступово розширювався, літературна критика, усвідомлюючи свою зростаючу значущість, формувала власні методологічні основи, визначала принципи оціновання літературних фактів, поступово переходячи до інтерпретаційної критики. Подібний шлях становлення методології власної критики пройшла більшість видів мистецтва.

Поступово сформувалася хореографічна, переважно балетна, критика, використовуючи принципи театральної, музичної критики, створюючи власні. «3 часів, коли балет став публічним видовищем, по мірі його професіоналізації починала формуватися і балетна критика (у газетах Франції, Англії, Італії та інших країнах», - зазначено в енциклопедії «Балет» [6, с. 50]. Критичні статті, рецензії, замітки, розміщені в періодичній пресі XVII-XIX ст. стали чи не єдиним джерелом (поряд із теоретичними трактатами, що відображали рівень розвиту техніки танцю, та мемуарами провідних діячів балету) для написання історії хореографічного мистецтва цього періоду. В історію хореографічного мистецтва вписана плеяда видатних критиків балету, завдяки яким, за відсутності засобів відеофіксації, ми можемо поринути в нюанси балетмейстерського та виконавського мистецтва певних епох, не задовольнятися сухим фактажем, що зберегли афіші та програмки вистав. Серед них Ф. Кастиль-Блаза, Т. Готьє у Франції, А. Хаскел у Великобританії, Я. Штелін, М. Яковлев, І. Бочаров, А. Волинський в Росії. У СРСР вагомий внесок у розвиток хореографічної критики внесли музикознавці та театрознавці Б. Асафьєв, О. Гвоздев, В. Івінг, А. та М. Гозенпуд, власне балетознавці Ю. Слонимський, В. Красовська, В. Гаєвський, Н. Аркіна, В. Ванслов, Н. Шереметьєвська та ін.

В Україні за радянських часів було сформовано основи вітчизняної шкколи балетної критики. Публікації Ю. Станішевського, М. Загайкевич, Т. Швачко, В. Туркевич заклали професійні підвалини української балетної критики. Нині підтримують високий рівень критично-оцінних виступів хореографічної тематики О. Чепалов, Г. Веселовська та ін. Однак декілька фахівців не в змозі заповнити лакуну, що утворилася навколо хореографічних процесів в аспекті критичного осмислення. 
Нині Україна фактично опинилася в ситуації наявності рецензій, критичних виступів із танцовальної тематики, але без професійної критики, великої кількості відвертої «макулатури» у цій сфері. В Україні немає жодного офіційно періодичного видання хореографічної тематики. Журнал «Танець в Україні та світі», започаткований доктором мистецтвознавства, професором Олександром Чепаловим фактично на голому ентузіазмі, «протримався» чотири роки, упродовж яких вийшло десять номерів. Головний редактор, а також автор більшості матеріалів, у традиціях найкращих світових зразків подібних видань, дотримувався паритету між історичними та гостроактуальними матеріалами, портретними замальовками, анонсами, репортажами з фестивалів та конкурсів тощо. На жаль, не отримавши підтримки державних структур, в ситуації низької вербальної активності професійної спільноти, відсутності у більшості фахівців сфери хореографічного мистецтва сформованого ставлення до критики як необхідної умови розвитку танцювальної культури засновник журналу, маємо надію тимчасово, втратив інтерес до подальшого його видання.

Хоча у світі є чимало прикладів танцювальних часописів, що десятиліттями не втрачають популярності. У Великій Британії виходить один з найстаpiших - «Dancing Times», перпий випуск якого побачив світ у 1910 p. Із 1995 p. видається «Dance Europe», що значно розширив географічний діапазон дописувачів, в якому періодично висвітлюються події європейських сценічних майданчиків, прем'єрні вистави, розміщуються репортажі з хореографічних навчальних закладів.

Одним з найвідоміших часописів, спеціально присвячених проблемам танцювального мистецтва, $€$ «Dance Magazine», що виходить у Сполучених Штатах Америки з 1927 р. 12 разів на рік. І це попри те, що в країні видаються такі науково-популярні видання про танець: «Ballet Review» (виходить з 1965 p.), «Dance Spirit», «Dance Teache», «Pointe» тощо.

На теренах колишнього Радянського Союзу неабиякої популярності набув журнал «Радянський балет» (виходить з кінця 1981 р. 6 разів на рік). Нині це журнал «Балет», але, на жаль, він не є загальнодоступним в Україні. 3 кінця 1999 р. видається «Лінія»- своєрідний додаток до журналу «Балет» у газетному форматі, а у 2012 р. з'явився всеросійський журнал для дітей (від 10 до 16 р.) «Студія Антре», основне завдання якого - залучення молоді до хореографічного мистецтва.

У Санкт-Петербурзі виходить відомий журнал «РROTанець». Найоперативніше реагує на подіі сьогодення однойменний сайт www.protanec.com, на якому час від часу з'являються матеріали, приевячені подіям в Україні, іноді значно докладніші, ніж у нашій країні. 
Наприклад, канал Megogo наживо транслював з Жовтневого палацу виставу Поклітару «Жізель» (уже не прем’срну), здасться, лише для того, аби за тисячу кілометрів, у Санкт-Петербурзі, знайти відгук у професійного критика балету Ольги Шкарпеткиної у статті «Ромашки спрятались, поникли лютики» [7]. Адже навіть прем'сра в Україні у квітні 2016 р. не викликала появи того професійного критико-оцінного дискусійного поля, на яке очікує вже багато років Раду Поклітару, наголошуючи у багатьох інтерв'ю на образливій відсутності реакщії з боку вітчизняних балетознавців. Чи то втрата традицій професійної балетної критики, чи відверте ігнорування хореографічного простору? Зазвичай, телевізійні репортажі та журналістські газетно-журнальні замітки обмежуються анотаційно-рекламним змістом.

Можливо, подібна ситуація характерна лише для подій сучасної хореографії та пояснюсться неусталеністю естетико-мистецтвознавчих підходів до аналітичного осмислення подібних явищ? Однак, балетні вистави Національної опери України також не одержують належної уваги.

Марними були намагання відшукати після прем'ери 3 липня 2016 р. балету Аніко Рехвіашвілі «Снігова королева» на сцені Національної опери України імені Т. Г. ШІевченка достойну уваги професійних практиків реакцію критиків. Крім кількох матеріалів, написаних журналістами, відверто далекими від балетного театру та від хореографічного мистецтва в цілому, практично не було реакції з боку балетознавців, театрознавців.

До подібних публікацій вдається, на жаль, і одна з найтиражніших газет «День». Рецензія Тетяни Поліщук «Трохи холоду в спеку» від 5 липня 2016 р. [4] відверто здивувала, оскільки авторка, здавалося б, спеціалізується на балетній тематиці. Чого лише варті такі претензії: «... навіть діти говорили: «Не вірю!», коли Герда майже весь час танцос на сцені в тоненькому платтячку (i коли дома знаходиться серед друзів напередодні Різдва, i коли мандрує по морозу і завірюсі у пошуках зниклого Кая, i коли марить у чарівному саду, і в палаці, до якого іiі привели Ворони, і коли вступає у двобій зі Сніговою королевою у іiі льодовому палаці), мабуть, логічно хоча б накинути на плечі героїні якусь хустину. Бо навіть зараз, коли на дворі спека, цей дисонанс ріже око публіці» [4]. Рецензенту реквізитно-побутові аспекти здалися значно важливіпими за можливість професійного аналізу композиційних, акторськовиконавських. I це не дивно, адже Поліщук резюмує: «...вистава вийшла... легенькою та візуально симпатичною» [4].

Заради справедливості слід зазначити, що в Україні збереглася традиція висвітлення подій хореографічного життя у газетах, серед них найактивніше залучена до процесу «День», де авторство критичних статей найчастіше належить не лише вже згаданим О. Чепалову та Г. Веселовський, які багато років тішать 
теоретиків і практиків хореографії, а також численних поціновувачів цього мистецтва високим професійним рівнем критично-оцінних матеріалів, а й Л. Тарасенко, Т. Поліщук та ін. Також значно рідше до танцювальної тематики звертаються газети «Сьогодні» (А. Пасютіна, А. Школьна та ін.), «Вечірній Київ» (М. Катаєва та ін.), «Український тиждень» та ін. Однак це відбувається доволі рідко, висвітлюється переважно балетна сфера. Наприклад, за п'ятнадцять років проведення в Україні наймасштаб-нішого фестивалю-конкурсу народної хореографії імені Павла Вірського, де беруть участь сотні професійних та аматорських танцювальних колективів, не вийшло жодної професійної критичної статті, що містила б мистецтвознав-чий аналіз продемонстрованих хореографічних творів, виявляла 6 тенденції розвитку народно-сценічного танцю тощо. У цілому спостерігається досить прохолодне ставлення до подій хореографічної культури з боку засобів масової інформації.

Останнім часом активізувалося обговорення балетних вистав на Інтернетфорумах, також окремі блогери реагують на певні події. Однак, естетикофілологічний рівень подібних виступів, зазвичай, не дає змоги віднести їх до належного рівня критичного осмислення подій.

А чи потрібна хореографічна критика сьогодні, у добу, коли не сам твір, а процес його сприйняття глядачем, не ідеї автора, а поліваріантність тлумачення реципіснтом стає основним? Безумовно, ніхто не заперечус відносність істини критичного оцінювання навіть найтитулованіших фахівців, розімкненість, незавершеність критичних суджень, неперервність переоцінювання одного й того ж мистецького явища.

Однак незаперечним є те, що критика діє як механізм саморегуляції художньої культури, одночасно є й реакцією на твір і спонукальним поштовхом до творчості.

Часто від митців можна почути вислови: «Нехай сам щось зробить, а потім критикує». Федір Михайлович Достосвський, реагуючи на подібні закиди, писав: «Критика так само природна і таку ж має законну роль в справі розвитку людського, як і мистецтво. Вона свідомо розбирає те, що мистецтво представляє нам тільки в образах» [3].

Хореографи-практики скільки завгодно можуть проголошувати, що вони не потребують оцінки, що їх не цікавить думка рецензентів і навіть глядачів, що справжній митещь орієнтується лише на власні критерії. Насправді мистецтво виконує свої функції лише за оцінного до нього ставлення. Незатребуваний твір мистецтва, такий, що не є цінним для даного суспільства, ніби не існує. Визнання, увага критики, навіть у вузькому колі, дуже часто рівноцінна народженню твору.

Наукова новизна статті полягає у виявленні проблем сучасної критики хореографічного мистецтва в Україні. 
Висновки. Традиції критичного осмислення подій хореографічного мистецтва, що народжувались 3 моменту формування європейського балету як самостійного видовища (сер. XVIII ст.), підтримувалися та розвивалися упродовж всісї історії його розвитку. Закладені за радянських часів основи української професійної школи балетних критиків, на жаль, уповільнили розвиток у сучасній Україні, хоча окремі мистецтвознавці продовжують дотримуватися високих критеріїв критично-оцінних виступів. Відсутність часопису, спеціально присвяченому хореографічній культурі України, ігнорування подій танцювального життя засобами масової інформації негативно позначається як на діяльності митців, так і збіднює палітру мистецьких уподобань суспільства.

Нині в Україні відсутний брак професійних критиків хореографічного мистецтва, що знаються на історії вітчизняного та світового балету, розуміють його поступ. Можна припустити, що пожвавлення практичної хореографічної сфери (збільшення кількості оригінальних балетмейстерських творів, розширення фестивально-конкурсного руху, поява нової генерації обдарованих виконавців тощо) неодмінно сприятиме відродженню традицій розгалуженої професійної хореографічної критики. Також можна сподіватися на пожвавлення не лише вузькопрофесійного хореографічного життя, а й широкого інтелектуального осмислення подій.

\section{Список використаних джкерел}

1. Барабанов Е. К критике критики [Электронний ресурс] / Е. Барабанов // Художественный журнал. - 2003. - № 48/49. - Режим доступа : http://xz.gif.ru/ numbers/48-49/kritika-kritiki. - Загл. с экрана.

2. Безклубенко С. Мистецтво: терміни та поняття : енцикл. У 2 т. Т. $1 . /$ С. Безклубенко. - Київ : Ін-т культурології АМУ, 2008. - 240 с.

3. Достоевский $\Phi$. Записки о русской литературе [Электронный ресурс]/ Ф. Достоевский. - Режим доступа : http://www.croquis.ru/2345.html. - Загл. с экрана.

4. Поліщук Т. Трохи холоду в спеку. Балет «Снігова королева»- остання прем'єра 148-го сезону Національної опери України [Електронний ресурс] / Т. Поліпук. - Режим доступу : https://day.kyiv.ua/uk/article/kultura/trohy-holoduv-speku - Назва з екрану.

5. Поляков О. Ю. Эстетическая теория Джозефа Аддисона / Ю. О. Поляков // XVIII век: искусствожить и жизнь искусства : сб. науч. тр. 2004. - C. 253-275. 
6. Суриц Е. Я. Балетоведение / Е. Суриц, Н. Чернова, О. Петров// Балет : энцикл. - 1981. - С. 50-54.

7. Шкарпеткина О. Ромашки спрятались, поникли лютики [Електронний pecypc] / О. Шкарпеткина // Рготанец. - Режим доступа : http:/www.protanec.com/ single-post. - Загл. с экрана.

\section{References}

1. Barabanov, E. (2003). To criticism of criticism. Khudozhestvennyi zhunal [Art magazine], [online] Available at: 〈http://xz.gif.ru/numbers/48-49/kritika-kritiki > [Accessed 20 November 2003].

2. Bezklubenko, S. (2008). Art: terms and concepts: Encyclopedic edition. In 2 vol. vol. 1. Kyiv: Institute of Cultural Studies of Academy of Arts in Ukraine.

3. Dostoyevsky, F. (2013). Notes on Russian Literature, [online] Available at: http://www.croquis.ru/2345.html [Accessed 20 November 2013].

4. Poliakov, O. (2004). Joseph Addison's aesthetic theory. XVIII vek: iskusstvo zhit i zhizn iskusstva: sbomik nauchnwh tmudov [The 18th century: the art of living and the life of art: a collection of scientific papers], pp. 253-275.

5. Polishchuk, T. (2016). A bit of cold in the heat. The «Snow Queen» ballet - the last premiere of the 148th season of the National Opera of Ukraine. Day, [online] Available at: https//day.kyiv.ua/uk/article/kultura/trohy-holodu-v-speku [Accessed 2 November 2016].

6. Shkarpetkina, O. (2016). Chamomiles hid, buttercups drooped. Pro tanec [About dance], [online] Available at: <http//www protanec.com/single-post $>$ [Accessed 22 April 2016].

7. Surits, E., Chernova, N., and Petrov, O. (1981). Ballet Studies. Balet: enciklopedija [Ballet: encyclopedia], pp. 50-54.

Midzuncska A. M., 2016 